\title{
The first Cenozoic spinicaudatans from North America
}

\author{
Alycia L. Stigall, ${ }^{1}$ Roy E. Plotnick, ${ }^{2}$ and Lisa E. Park Boush ${ }^{3}$ \\ ${ }^{1}$ Department of Geological Sciences and OHIO Center for Ecology and Evolutionary Studies, Ohio University, Athens, Ohio 45701, USA \\ 〈stigall@ohio.edu〉 \\ ${ }^{2}$ Department of Earth and Environmental Sciences, University of Illinois at Chicago, Chicago, Illinois 60607, USA 〈plotnick@uic.edu〉 \\ ${ }^{3}$ Center for Integrative Geosciences, University of Connecticut, Storrs, Connecticut 06269, USA 〈lisa.park_boush@uconn.edu〉
}

\begin{abstract}
A new spinicaudatan species, Estherites? jocelynae new species, is described from more than fifty specimens collected from the Medicine Lodge Formation (early Oligocene) of the Beaverhead Basin in southwestern Montana, USA. This is the first spinicaudatan species reported from Cenozoic strata of North America and is the second-youngest fossil clam shrimp described globally. The new species extends the range of the superfamily Estheriteoidea into the Paleogene. Carapaces of E.? jocelynae n. sp. are preserved as a calcium carbonate replacement of the original chitin-calcium-phosphate structure, which is an uncommon style of preservation for spinicaudatans. The unique preservation coupled with the range extension suggests that the sparse Cenozoic fossil record of spinicaudatans may be partly attributable to preservation bias related to geochemical conditions rather than exclusively to diversity decline following the end-Cretaceous mass extinction. The presence of E.? jocelynae n. sp. in the Medicine Lodge Formation indicates that lakes in the Beaverhead Basin experienced seasonality and fluctuating lake levels with at least some drying at the lake margins. The ecological inferences support previous paleoenvironmental interpretations based on paleobotanical and other faunal evidence.
\end{abstract}

\section{Introduction}

Spinicaudatans have been important components of lacustrine ecosystems since the late Paleozoic (Park and GierlowskiKordesch, 2007). Spinicaudatan fossils are significant paleoenvironmental indicators; because most species only occupy ephemeral pools of freshwater, their presence indicates a seasonal climate (Vannier et al., 2003). In addition, this clade is widely used for continental biostratigraphy in Mesozoic strata (Shen et al., 2004; Kozur and Weems, 2010). Paradoxically, even though the number of preserved lake deposits increases during the Cenozoic relative to the Mesozoic (GierlowskiKordesch and Kelts, 2000), the Cenozoic record of spinicaudatans is extremely sparse. To date, no spinicaudatan species have been formally described from Neogene strata and fewer than ten spinicaudatan occurrences have been described globally from Paleogene strata (listed in Shen et al., 2006). The substantial gap in the fossil record of spinicaudatans limits the ability to make inferences about the evolutionary history of the clade. Mesozoic faunas included many spinicaudatan families reflecting greater diversity and disparity than represented among the three modern families. It is currently unclear whether spinicaudatan diversity declined due to the CretaceousPaleogene mass extinction, climatic or tectonic changes in the early Cenozoic, and/or preservational bias. The new species described herein is the first record of a fossil spinicaudatan species from the Cenozoic of North America. We discuss the preservation, evolutionary implications, and ecological interpretations of these new specimens.

\section{Geologic setting}

The fossil spinicaudatans were collected from the early Oligocene Medicine Lodge Formation in Beaverhead County, Montana (Fig. 1) by J.B. Orr during the 1960s. The specimens described herein were collected from a single locality along a small bluff on Anton Creek (Sec. 27, 28, T11S, R12), which the authors georeferenced to 44.8527 latitude, -113.0239 longitude, uncertainly $210 \mathrm{~m}$.

The Medicine Lodge Formation and associated sedimentary units within the Beaverhead Basin include interbedded thinto-thick shales and sandstones, including a basal conglomerate and a localized coal layer near the top, with noticeable vertical and lateral variations (Scholten et al., 1955; Becker, 1969; DeVore and Pigg, 2010; Lielke et al., 2012). These facies represent fluvial, lacustrine, fan-delta, and paludal facies (M'Gonigle and Darymple, 1996) that were deposited within a structural basin bounded by the hanging wall of a Paleogene low-angle fault on the west and the low-angle normal fault to the east (Scholten et al., 1955; Becker, 1969; DeVore and Pigg, 2010; Lielke et al., 2012). Based on paleobotanical data (e.g., Scholten et al., 1955; Becker, 1969; DeVore and Pigg, 2010; Lielke et al., 2012), the basin was estimated to have an elevation of $\sim 1600 \mathrm{~m}$ above sea level.

Becker (1969) described three florules from Paleogene basinlake deposits in Beaverhead County, Montana: the Christensen, Horse Prairie, and Medicine Lodge florules. The Medicine Lodge Florule is the youngest of these and crops out along several adjacent tributaries of Medicine Lodge Creek. The age of the 


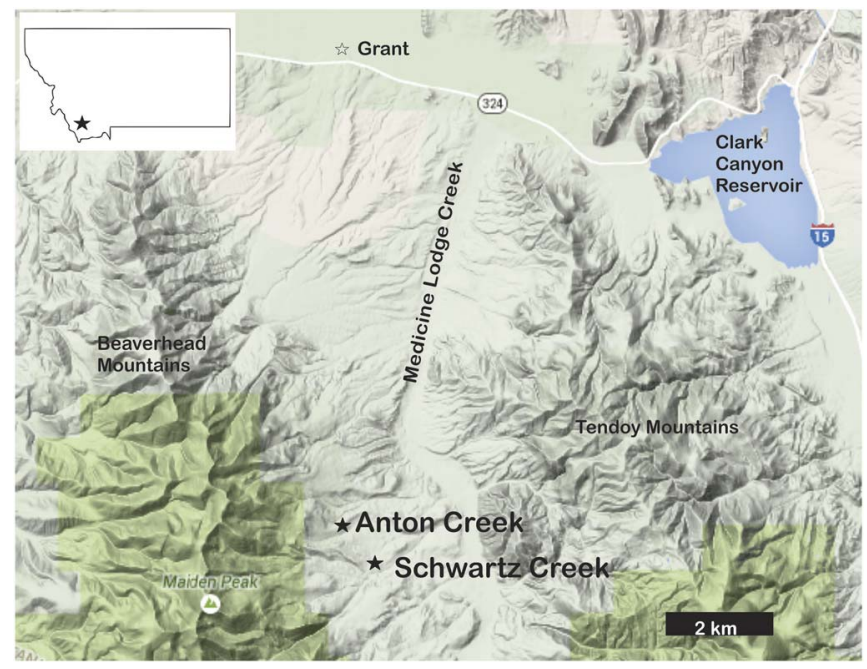

Figure 1. Locality map of the Beaverhead Basin in southwestern Montana All spinicaudatan specimens were collected from the Anton Creek locality along a tributary of the Medicine Lodge Creek. Correlative layers at a locality along Schwartz Creek produced fossil ostracodes, plants, and insects, but no spinicaudatans.

Medicine Lodge Formation is constrained by radiometric dates and refined using biotic data. Tuffs at the base of the sedimentary sequence at Medicine Lodge and Horse Prairie Basins exhibit ages of $46.04 \pm 0.15 \mathrm{Ma}$ to $45.0 \pm 0.13 \mathrm{Ma}$, indicating the initiation of basin fill during the middle Eocene (M'Gonigle and Dalrymple, 1993, 1996), whereas overlying basalts have been dated at 27.5 Ma (late Oligocene; Janecke et al., 1999). Within this constraint, Lielke et al. (2012) determined that the preponderance of the evidence, including floral similarity with other sites, was consistent with an earliest Oligocene age (Rupelian Stage, Orellan NALMA) for the three florules described by Becker (1969).

The Medicine Lodge Formation preserves a diverse biotic assemblage. The described flora contains 94 species belonging to 66 genera, including both dicots and conifers, representing a mixed forest biome (Wing, 1987; Graham, 1999; DeVore and Pigg, 2010). In addition to the spinicaudatans, the invertebrate component of the fauna includes insects (including caddisfly larval cases), freshwater gastropods tentatively assigned to Planorbidae, the bivalve Sphaerium sp., and several species of ostracodes (Becker, 1969; Lewis, 1972). Vertebrates include relatively common fish scales and rare articulated specimens provisionally assigned to Hiodontidae and Catostomidae. With the exception of an abstract by Cavender (1977), the fish fauna remains undescribed. Becker (1969) also mentioned the presence of large, unidentified mammal bones.

\section{Materials and methods}

Spinicaudatan specimens were examined using light and scanning electron microscopy. SEM analyses were conducted using a JEOL JSM-6390 at the Ohio University Institute for Corrosion and Multiphase Technology under low vacuum conditions. Preservation was assessed via energy dispersive spectroscopy (EDS) equipment, Genesis from EDAX.

Repositories and institutional abbreviations.-This collection was made by J.B. Orr for an unfinished thesis at the University of Chicago sometime in the 1960s and had been in storage at the University of Illinois at Chicago (UIC) since that time. All materials from the Orr collection at UIC, including those examined herein, have been transferred to Yale Peabody Museum (YPM), which also houses extensive paleobotanical collections from the same locality that were transferred from the New York Botanical Gardens.

\section{Systematic paleontology}

Phylum Arthropoda von Siebold, 1848

Subphylum Eucrustacea Walossek, 1999

Class Branchiopoda Latreille, 1817

Order Diplostraca Gerstaecker, 1866

Remarks.-Spinicaudata, Laevicaudata, and Cyclestherida were once united in the paraphyletic "order Conchostraca." Recent phylogenetic analyses (e.g., Richter et al., 2007; Olesen, 2009) have cogently demonstrated that this grouping is paraphyletic. However, the monophyly of the Spinicaudata, which includes the vast majority of "clam shrimp," is firmly established (e.g., Olesen, 2000, 2009; Stenderup et al., 2006; Richter et al., 2007; Schwentner et al., 2009). A recent review by Astrop and Hegna (2015) examined the relationships among living and fossil spinicaudatans, and their recommendations are followed herein. The systematic terminology used herein follows that of Olesen (2000) and Martin and Davis (2001) for higher-level classification and follows Chen and Shen (1985) for superfamilial and lower levels. Measurements and terminology of carapace features follow Tasch (1987).

As implied by common name "clam shrimp," conchostracans are sometimes mistaken for bivalves and vice versa due to their similar gross morphologies of bivalved shells with concentric growth lines. The lightly biomineralized chitinous carapace, ornamentation and growth patterns, and life habits of conchostracans produce a suite of features that allow confident differentiation, many of which are described by Tasch (1987). Conchostracan valves typically do not disarticulate postmortem and frequently are preserved overlapping on bedding planes with conspicuous wrinkles due to desiccation and compaction (e.g., Figs. 2.5, 3.1, 5.1; Li and Batten, 2005, figs. 3, 4; Shen et al., 2006, fig. 4; Stigall et al., 2014, fig. 5). Conchostracan carapaces range from elongate to ovate, but in general are characterized by a narrower anterior and a broader posterior angle (see Chen and Shen, 1985; Tasch, 1987; Scholze and Schneider, 2015). Conchostracan growth bands are thickest and often more strongly preserved at the distal margin (e.g., Fig. 5.1, 5.2, 5.5; Orr et al., 2008, fig. 5; Astrop and Hegna, 2015, fig. 4). Outer layers of carapace growth bands are often replaced or remineralized in patches or as overgrowths (e.g., Fig. 3.1, 3.3; Shen et al., 2006, fig. 4; Stigall et al., 2008, figs. 6, 12; Gallego et al., 2011, fig. 5). Growth bands frequently appear to be shingled along the distal carapace margin (e.g., Fig. 4.1; Stigall et al., 2014, figs. 5, 6) and sometimes include radial canals (lirae) or serrations for setal exit (e.g., Fig. 4.7; Li and Batten, 2005, fig. 3; Boukhalfa et al., 2015, fig. 4). Finally, conchostracans rarely occur in isolation; they more typically occur in massive bedding-plane concentrations (e.g., Fig. 5.3; Monferran et al., 2013, fig. 3). 
The specimens described herein meet each of these criteria for inclusion within the "Conchostraca."

Suborder Spinicaudata Linder, 1945

Superfamily Estheriteoidea Zhang and Chen in Zhang et al., 1976

Family Estheriteidae Zhang and Chen in Zhang et al.,1976

Genus Estherites? Kobayashi and Huzita, 1943

Type species.—Estheria mitsuishii (Kobayashi and Huzita, 1942) Kobayashi and Huzita, 1943 from the Upper Cretaceous (Conianian), Nenjiang Formation, Jilin Province, northeast China.

Diagnosis.-From Li and Batten (2005). Carapace of moderate size, gently convex, elliptical or elongate-subquadrate in outline. Umbo projecting somewhat beyond dorsal margin; growth bands ornamented by fine lirae that are connected by bars in various directions on ventral part of carapace; those on dorsal side sculptured only with fine radial lirae.

Occurrence.-Triassic? or Cretaceous through Oligocene of China, Japan, South Korea and western North America.

Remarks.-Estherites is a genus of $\sim 15$ species of relatively small (typically $4-10 \mathrm{~mm}$ in length) spinicaudatans characterized by an oval to elliptical carapace with a subcentally located umbo (Zhang et al., 1976). Growth bands are typically wide throughout much of the carapace and may narrow in the distal third. The umbonal region is ornamented with punctae, which align into weak radial lirae near the dorsal margin. In some species, such as E. corrugatus, ornamentation is weakly impressed throughout the carapace. Growth band count varies from relatively few $(\sim 12)$ to many (40+). A comprehensive species list with associated references is provided in $\mathrm{Li}$ and Batten (2005).

The Medicine Lodge spinicaudatans exhibit most of the key diagnostic features of Estherites including size, elliptical shape, carapace ratios, number and width of growth bands, and weakly impressed ornamentation in the umbonal region with lirae expressed at the distal margin. The lirae and radial ornamentation are very weakly developed in this new species, which may be a taphonomic artifact or may indicate that the Medicine Lodge specimens belong to a new, yet undescribed genus. At this point, we prefer to assign the new species to Estherites while noting this uncertainty because the carapace microstructure of specimens is not preserved well enough to definitively either include or exclude the new species from Estherites. In either case, the Medicine Lodge spinicaudatans are clearly referable to the family Estheriteidae. The documentation of this new species extends the geologic range of the Estheriteidae and places it among the very few clamp shrimp taxa known from Cenozoic strata. Among "conchostracans," only members of the spinicaudatan families Fushunograptidae, Loxomegaglyptidae, and Perilimnadiidae, the laevicaudatan family Lynceidae, and the cyclestherid family Cylclestheriidae have previously been documented from Cenozoic deposits (Shen et al., 2006).

Estherites? jocelynae Stigall new species

Figures 2.1-2.14, 3.1-3.3, 4.1-4.7, 5.1-5.8
Holotype.-YPM 531187, complete right carapace valve (holotype); YPM 531188, left valve; 531189, left valve, 531190 , complete left valve (paratypes). All type material was collected from the Anton Creek Locality of the early Oligocene (Rupelian Stage, Orellan NALMA), Medicine Lodge Formation, Beaverhead Basin, MT.

Diagnosis.-Thin carapace valves of medium size, elliptical to ovate in outline, umbo centrally located, extending slightly above hinge line; height to length ratio from 0.7 to 0.9 , valve convexity moderate; growth bands of two orders: flat growth bands $\sim 0.4 \mathrm{~mm}$ wide in umbonal and central carapace, and rounded growth bands $\sim 0.04 \mathrm{~mm}(40 \mu \mathrm{m})$ wide at distal margin. Weak radial lirae and wrinkles present on dorsal growth bands.

Occurrence.-Early Oligocene (Rupelian Stage, Orellan NALMA), Medicine Lodge Formation, Beaverhead Basin, MT. Orr's Anton Creek Locality, Sec. 27, 28, T11S, R12; 44.8527 N latitude, $-113.0239 \mathrm{~W}$ longitude, uncertainty $210 \mathrm{~m}$.

Description.-Carapace valves of moderate size and elliptical to oval in outline. Mean carapace length and height are $3.89 \mathrm{~mm}$ (range: $1.94-5.87 \mathrm{~mm}$ ) and $3.13 \mathrm{~mm}$ (range: $1.53-5.06 \mathrm{~mm}$ ), respectively (Table 1 ). The $\mathrm{L} / \mathrm{H}$ ratio averages 0.81 (range: $0.70-0.90$ ). Carapace growth is isometric (Fig. 6). Dorsal margin is weakly curved and relatively short (typically less than half of the valve length) with umbo centrally located. Anterior margin shorter and more tightly rounded than posterior. Maximum anterior bulge is approximately $0.38 \mathrm{x}$ distance from hinge line to ventral margin, and maximum posterior bulge located approximately $0.43 \mathrm{x}$ distance from hinge line to ventral margin. Maximum ventral bulge is located slightly anterior of center, approximately $0.38 \mathrm{x}$ distance from anterior to posterior of carapace.

Moldic specimens and those with preserved carapace valves exteriors record an average of eight (range: 7-14) flat growth bands $\sim 0.4 \mathrm{~mm}$ wide (e.g., Figs. $2.3,3.1,5.1,5.5$ ). The distal margins of these growth bands are demarcated by a topographic impression within the mold and/or a thickened region of preserved carapace. Many specimens preserve an internal mold of the carapace valve (e.g., Figs. 2.4, 2.7, 5.2, 5.3, $5.4,5.6)$ and, consequently, do not preserve any external ornament. One specimen (YPM 531189, Fig. 2.5, 2.8, 2.14) represents a carapace exterior and preserves a series of narrow concentric bands throughout the carapace, which suggests development of narrower growth bands mediodistally. Limited regions around the extreme distal margins of some specimens, notably specimens of the type series, preserve sets of narrow growth bands, $\sim 40 \mu \mathrm{m}$ wide, as siliceous molds (Figs. 2.13, $2.14,3.5)$. Weakly preserved ornamentation patterns of radial lirae and concentric wrinkles are present on some of these narrow, extreme-distal growth bands (Fig. 4.5). There is no evidence for radial ornamentation in the umbo or central region of specimens where that region has been preserved as a siliceous mold. The preservation of a consistent number of wide growth bands among internal molds coupled with the occasionally preserved narrow bands suggests that two stages of concentric band development occurred during ontogeny. 

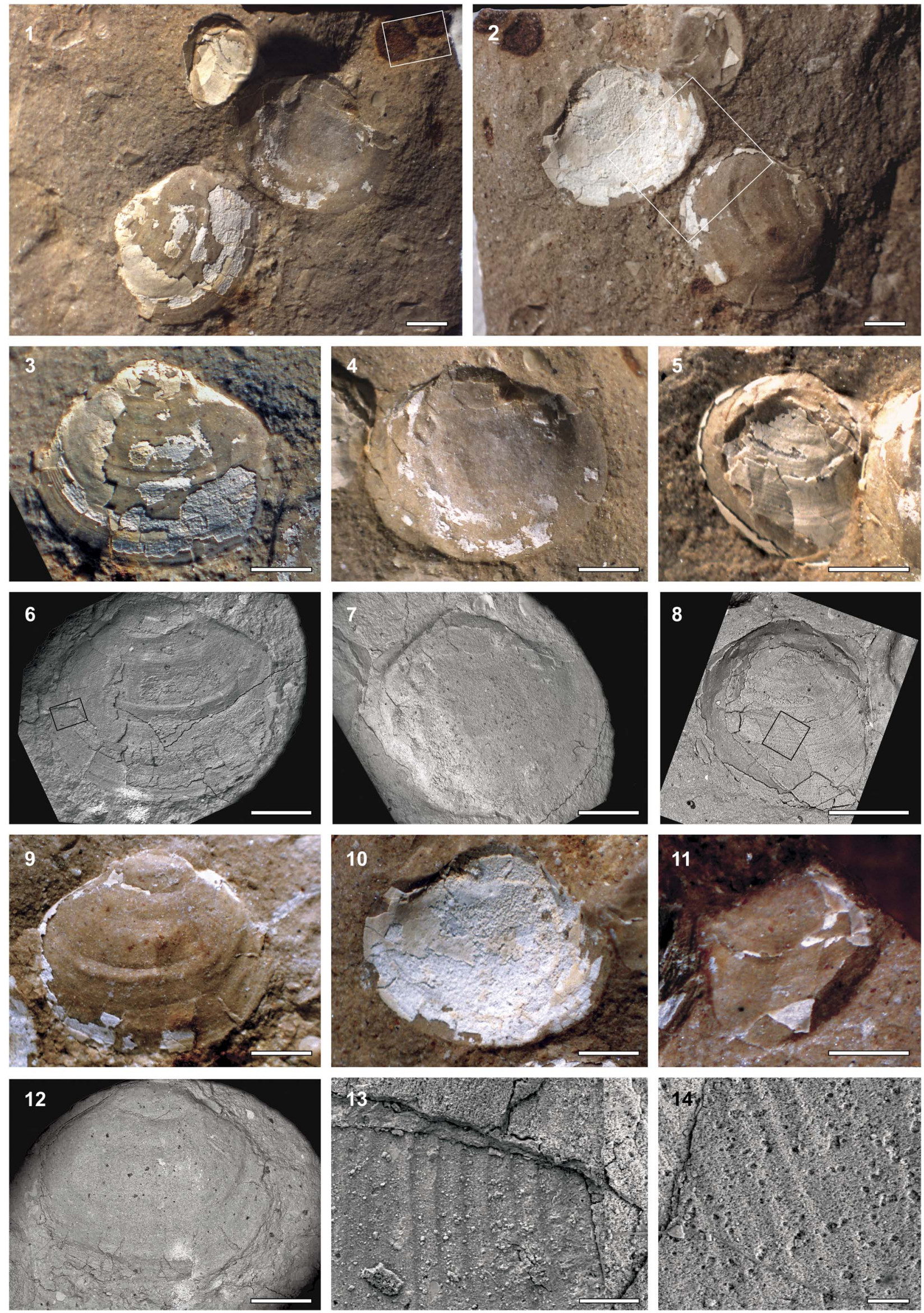

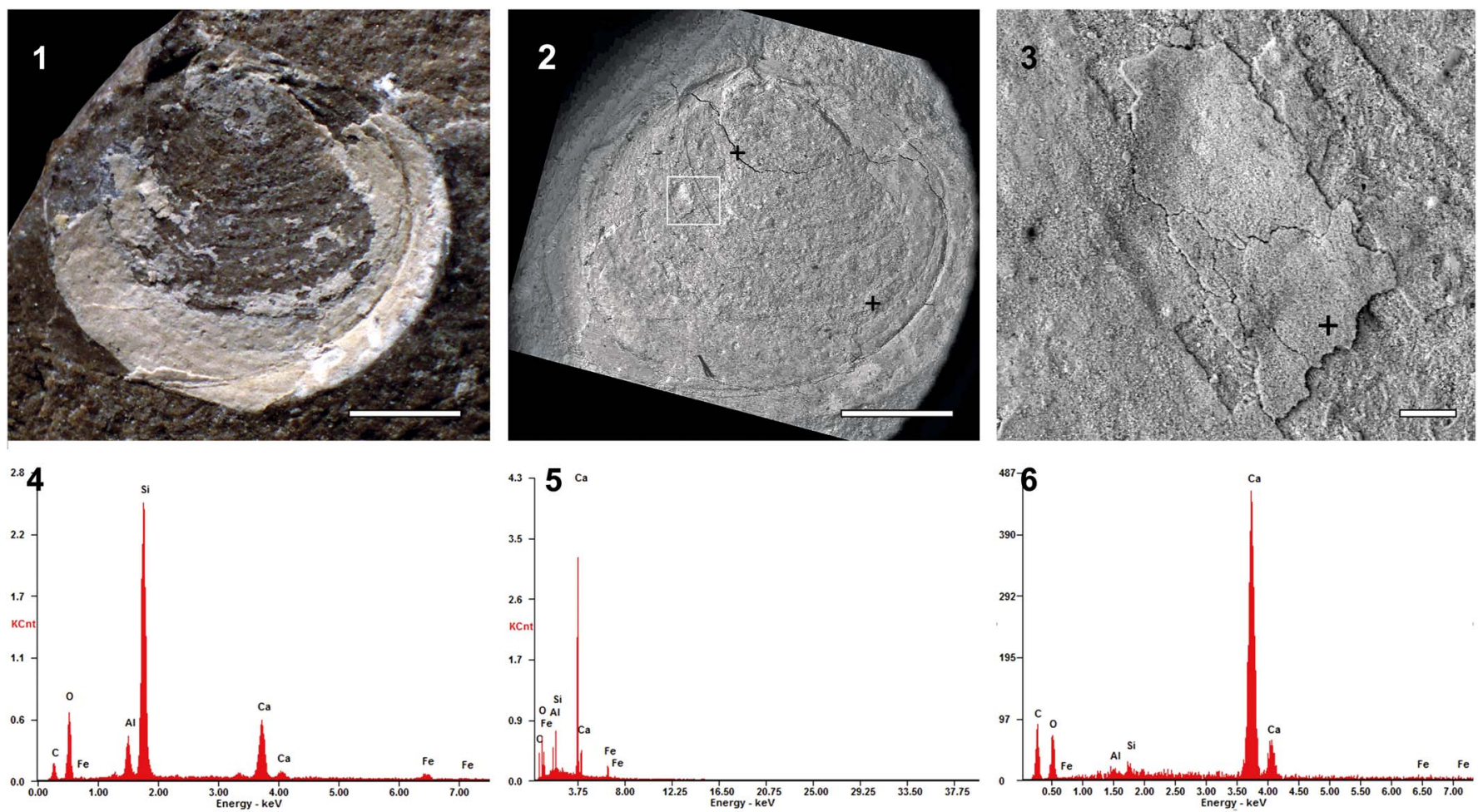

Figure 3. Images and energy dispersive x-ray spectral data for paratype YPM 531190 of Estherites? jocelynae n. sp. (1, 2) Photomicrograph and SEM image of entire left carapace valve, scale bar $=1 \mathrm{~mm} ;(\mathbf{3})$ close up of central carapace outlined with white box in Figure 3.2, note lack of detailed ornamentation on the preserved growth band, scale bar $=50 \mu \mathrm{m}$; (4) spectral data for centromedial location on carapace where growth bands have been exfoliated, marked as + in Figure 3.2, composition is dominated by silicates; (5) spectral data for posterodistal location on carapace where growth bands are preserved as a thick layer, marked as + on lower right of Figure 3.2, composition is dominated by calcium ions; (6) spectral data for central carapace where growth bands are preserved as a thick layer, marked as + on lower right of Figure 3.3, composition is dominantly calcium carbonate.

\section{Etymology.-Named after Jocelyn Ann Hembree.}

Materials.-Type material and 26 additional specimens (YPM 531191-531203, 531205-531214, 531217-531219). Additional morphological details of the types and other material are presented in the Appendix.

Remarks.-Estherites? jocelynae n. sp. exhibits the key morphological and ornamentation features of Estherites noted above. However, it is distinguished from all previously named species based on the carapace size and the number and width of growth bands. The maximum carapace length of E.? jocelynae is smaller than all other species of Estherites, except for Estherites? minutus Zhang and Chen in Zhang, Chen, and Shen, 1976, which reaches a maximum length of $4.0 \mathrm{~mm}$. Estherites? jocelynae $\mathrm{n}$. sp. can be distinguished from E.? minutus due to its more circular shape, larger size, higher $\mathrm{H} / \mathrm{L}$ ratio ( 0.81 vs. 0.73 ), more centrally located umbo, narrower distal growth bands, and wider medial growth bands. In addition, other species attributed to Estherites have more pronounced or larger radial lirae, course meshwork as part of their ornament, substantially larger carapace size, and/or an anteriorly (rather than centrally) positioned umbo.

\section{Preservation}

Specimens of Estherites? jocelynae n. sp. are preserved as combinations of fossilized carapace material and corresponding molds of the carapace interior and exterior surfaces (e.g., Fig. 2.1). Where present, the carapace material is preserved as a white opaque mineral that may be tinted orange (e.g., Fig. 2.2). Spectra obtained from EDAX analyses indicate that the white mineral is composed primarily of calcium ions with minor peaks at carbon and oxygen and accessory peaks for iron, silica, and aluminum (Figs. 3, 4). This carbonate-dominated composition differs from the elemental composition of the sedimentary background, in which calcium is negligible and aluminum and silicon ions are abundant (Fig. 4). The carbonate preservation also differs from the presumed chitin-calcium-phosphate composition of the original carapace material (for discussion of modern spinicaudatan carapace composition see Stigall et al., 2008; Astrop et al., 2015). This indicates the fossils represent

Figure 2. Part and counterpart specimens of the type series of Estherites? jocelynae n. sp. (1, 2) Part and counterpart slab with holotype specimen (YPM 531187 ) in lower center and two paratype specimens (YPM 531188, 531189), scale $=1 \mathrm{~mm}$, white boxes indicate boundaries of Figure 5.10 and Figure 4.1-4.4; $(3,6,9,12)$ photomicrograph and SEM images of the holotype part and counterpart (YPM 531187); distal edges of growth bands marked by depression in molds, whereas surface ornament preserved best near distal margins; $(\mathbf{4 , 7 , 1 0 , 1 2})$ photomicrograph and SEM images of the paratype YPM 531188 part and counterpart, scale $=1 \mathrm{~mm} ;(\mathbf{5}, \mathbf{8}, \mathbf{1 1})$ photomicrograph and SEM images of paratype YPM 531189 part and counterpart, scale $=1 \mathrm{~mm} ;(\mathbf{1 3})$ close up of distal growth bands of the holotype (YPM 531187) outlined in box in Figure 2.6, scale bar $=100 \mu \mathrm{m}$; (14) close up of centrally located growth bands of the paratype YPM 531189 outlined in box in Figure 2.8, scale bar $=50 \mu \mathrm{m}$. 

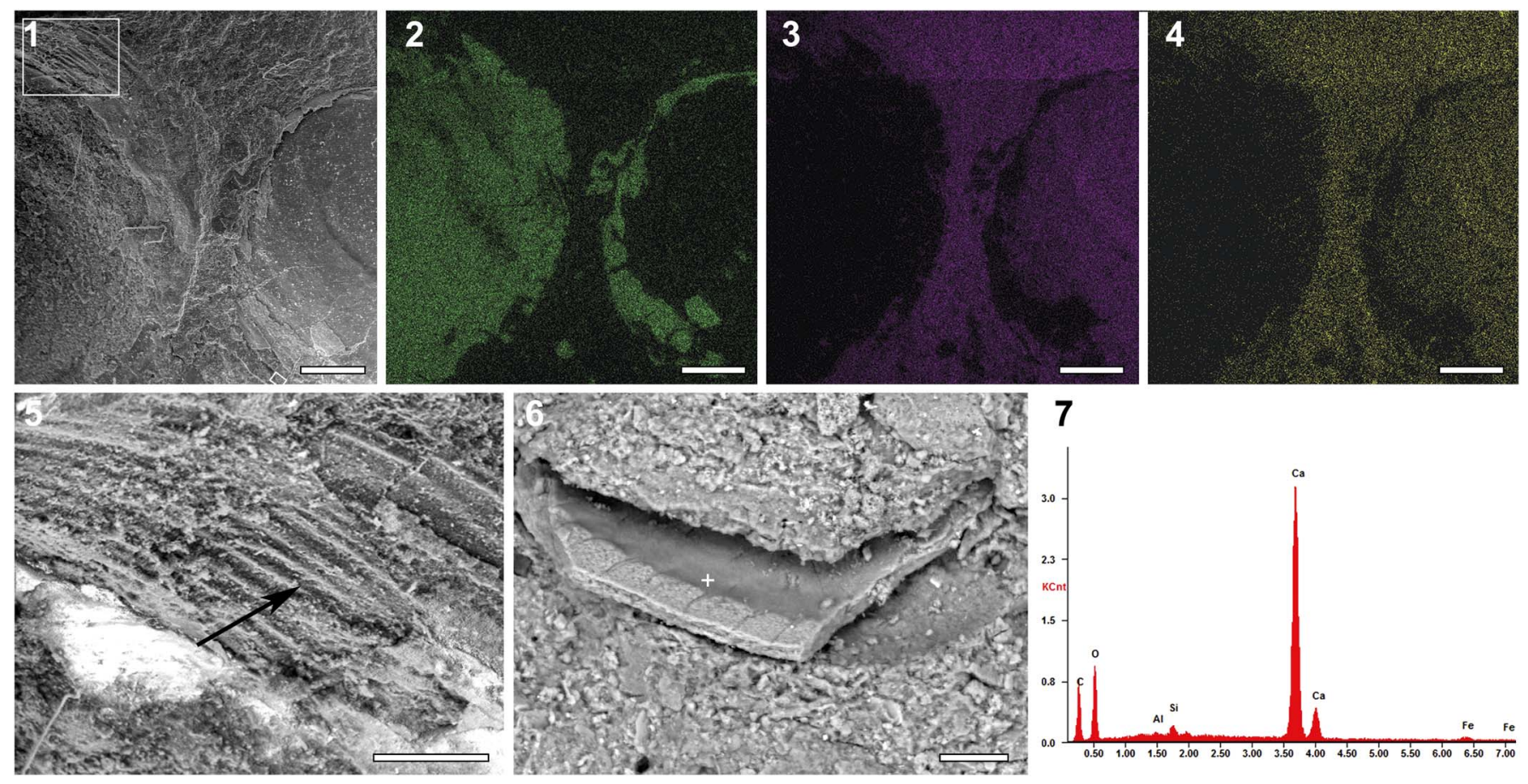

Figure 4. SEM images and energy dispersive X-ray spectral data for holotype counterpart (YPM 531187) and paratype counterpart (YPM 531188) of Estherites? jocelynae n. sp. (1) Image of the carapace margins of YPM 531188, left, and YPM 531187, right, as indicated by white box in Figure 2.2, scale bar $=500 \mu \mathrm{m} ;(2-4)$ EDAX map with same dimensions as Figure 4.1, scale bars $=500 \mu \mathrm{m}$; elemental maps of illustrate the relative concentrations of Ca, Si, and $\mathrm{Al}$, respectively. Areas with preserved growth bands have high calcium content but lack silica and aluminum and vice versa; (5) view of distal growth bands of paratype YPM 531188 outlined in the upper left corner white box in Figure 4.1, radial structures indicated by arrow, scale bar $=200 \mu \mathrm{m}$; (6) close up of distal margin of a growth band of the holotype (YPM 531187) outlined by the lower right white box in Figure 4.1, scale bar $=25 \mu \mathrm{m}$, notice the thickened distal edge, which corresponds with the stronger depressions marking the distal edge of the growth bands in moldic specimens; (7) spectral data for the growth band illustrated in Figure 4.6, location of scan marked as + in 4.6, composition is dominantly calcium carbonate.

replaced rather than recrystallized carapace material. In regions where a detailed mold of the carapace exterior is preserved (e.g., Figs. 2.13, 4.4-4.6), silicon is the primary ion (Fig. 3.3). Similar high-fidelity preservation via silica molds has been documented in other spinicaudatans, such as Carapacestheria disgregaris from the Jurassic of Antarctica (Stigall et al., 2008).

Compared to other fossil spinicaudatan carapaces, the preservation of the Beaverhead Basin specimens is unusual. Notably, although hundreds of fossil spinicaudatan species have been described, the elemental composition of carapaces has been explicitly tested for fewer than ten species. Thus sets of the comparative data are extremely limited. Most fossil species for which carapace compositions have been analyzed via EDAX are within the 'Estheriteoidea-Eosestheriodidea' group, and their carapaces have reported to be preserved primarily as recrystallized calcium phosphate or silica molds. This group includes Triassic specimens from Poland (Olempska, 2004), Jurassic specimens from Antarctica (Stigall et al., 2008), Namibia (Stigall et al., 2014), and China (Hethke et al., 2013), and
Cretaceous specimens of Madagascar (Stigall and Hartman, 2008). Another identified mode of spinicaudatan preservation, specifically related to exceptional preservation of soft tissues and appendages, is as organic-carbon residues associated with phyllosilicates (Orr and Briggs, 1999). Carbonate preservation of spinicaudatans has only previously been reported from the Jurassic specimens of western North America (Lucas and Milner, 2006). Notably, both carbonate and organic-carbon preservation result in lower resolution of carapace details than preservation as recrystallized calcium phosphate or silicic molds.

Although studies of spinicaudatan carapace taphonomy are limited, carbonate replacement or preservation has been studied within both arthropods and vertebrates preserved in freshwater environments. Calcium carbonate precursors have been observed to form from the breakdown of organic matter in aqueous solution (Berner, 1968) and have been implicated in the development of concretions as well as exoskeleton and softtissue replacement in insects and shrimp (McCobb et al., 1998;

Figure 5. Images of additional spinicaudatan and associated fossils. (1-7) Additional specimens of E.? jocelynae n. sp.: (1) complete right carapace valve (YPM 531191) and partial right? valve preserved with growth bands marked by calcium carbonate replacement (YPM 531192), scale bar = 1 mm; (2) posterior portion of a left carapace valve (YPM 531198) underneath the distal margin of another valve (YPM 531199), scale bar = $1 \mathrm{~mm}$; (3) dense assemblage of ironstained carapace molds (YPM 531205-531214) on the underside of slab containing the holotype specimen illustrated in Figure 2.1, scale bar = 5 mm; (4) anterior portion of a carapace (YPM 531203), scale bar = $1 \mathrm{~mm}$; (5) two carapaces replaced with carbonate (YPM 531200, upper; 531201, lower), scale bar $=1 \mathrm{~mm}$, margins of these specimens appear warped, probably from desiccation before burial; (6) laterally compressed specimen (YPM 531202), scale bar = $1 \mathrm{~mm}$; (7) E.? jocelynae n. sp. specimen YPM 531218 intersected by an iron-rich Planolites burrow, scale bar = 5 mm; (8) gastropod, YPM 531204, scale bar $=1 \mathrm{~mm} ;(\mathbf{9})$ bedding-plane assemblage of associated fauna including ostracodes and macerated insect exoskeleton (YPM 531216), scale bar $=1 \mathrm{~mm}$; (10) SEM image of iron-rich burrow, field of view indicated by white box in Figure 2.1, scale bar $=250 \mathrm{~mm}$; (11), assemblage of Planolites burrows (YPM 531215) on the holotype slab in Figure 2.1, scale bar $=5 \mu \mathrm{m}$. 

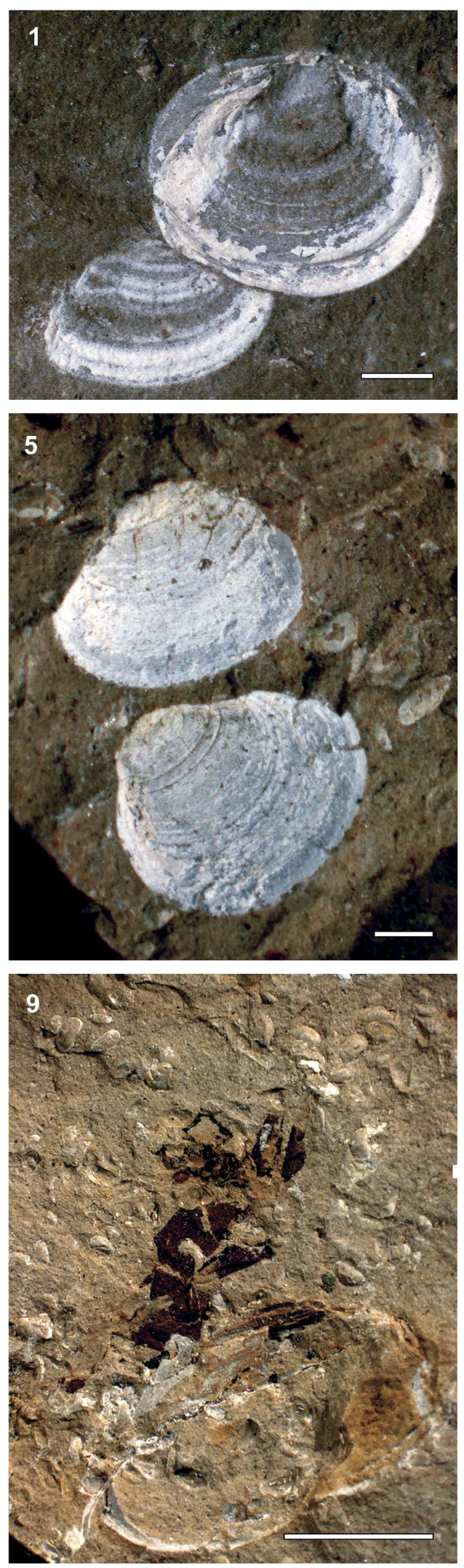
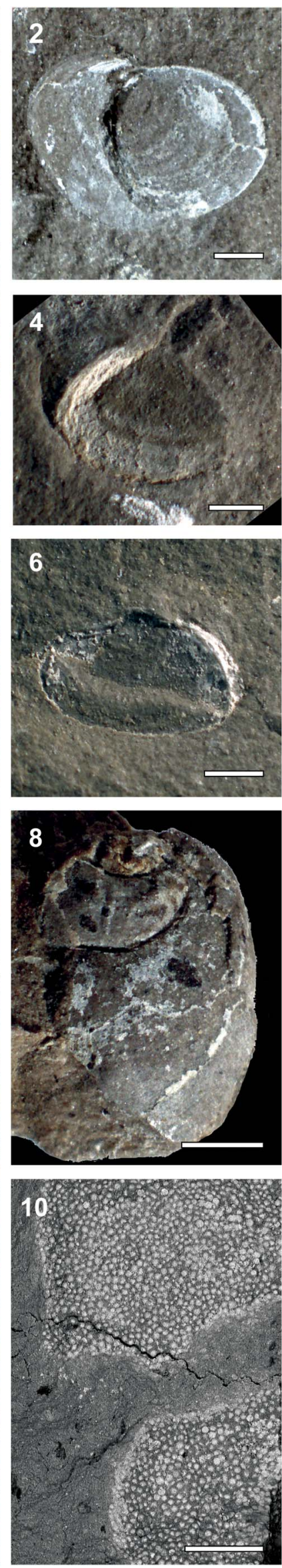
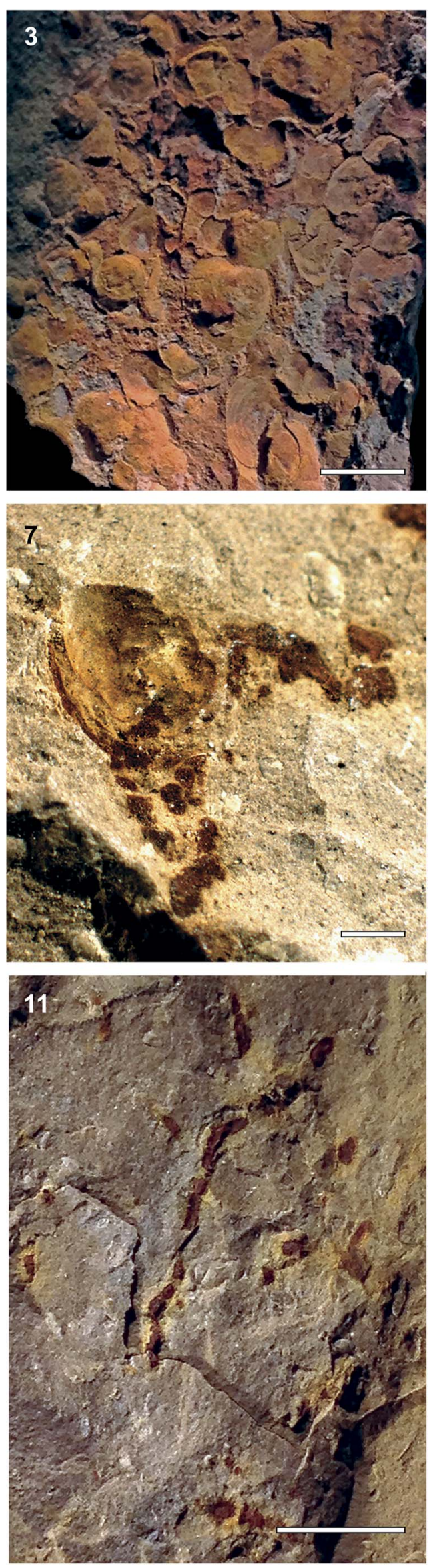
Table 1. Summary of measured data for Estherites? jocelynae n. sp. specimens. Length $=$ maximum carapace length; Height $=$ maximum distance from the dorsal margin to the hinge line; Hinge = length of the hinge line; $\mathrm{A}=$ distance from the maximum anterior bulge to the dorsal margin; $\mathrm{B}=$ distance from the maximum posterior bulge to the dorsal margin; $\mathrm{C}=$ distance from the maximum ventral bulge to the most anterior part of the valve; $\mathrm{D}=$ distance from center of the umbo to the anterior margin; units $=\mathrm{mm} ; \mathrm{N}=$ number of specimens measured.

\begin{tabular}{lcccr}
\hline Character & mean & median & range & $\mathrm{N}$ \\
\hline Length & 3.88 & 3.94 & $1.94-5.87$ & 22 \\
Height & 3.13 & 3.25 & $1.53-5.06$ & 23 \\
$\mathrm{~A}$ & 1.23 & 1.22 & $0.58-1.82$ & 9 \\
$\mathrm{~B}$ & 1.34 & 1.40 & $0.66-1.82$ & 8 \\
$\mathrm{C}$ & 1.49 & 1.51 & $0.95-2.26$ & 10 \\
$\mathrm{D}$ & 1.07 & 0.98 & $0.52-1.93$ & 10 \\
Hinge & 1.67 & 1.75 & $0.87-2.20$ & 7 \\
Height/Length & 0.81 & 0.80 & $0.70-0.90$ & 21 \\
Hinge/Length & 0.45 & 0.47 & $0.31-0.54$ & 7 \\
A/Height & 0.38 & 0.38 & $0.25-0.46$ & 9 \\
B/Height & 0.43 & 0.42 & $0.36-0.52$ & 8 \\
C/Length & 0.38 & 0.37 & $0.30-0.45$ & 8 \\
D/Length & 0.26 & 0.27 & $0.19-0.36$ & 8 \\
\hline
\end{tabular}

Sageman et al., 1999; Park and Downing, 2001; MartínezDelclòs et al., 2004). The degree that phosphate is replaced by carbonate within vertebrate bioapatite has been shown to vary among depositional environments due to local geochemical conditions (Keenan et al., 2015), variations in pH (Sagemann et al., 1999), or as a byproduct of bioerosion by aquatic microorganisms (Fernández-Jalvo et al., 2016). In some instances (e.g., Fernández-Jalvo et al., 2016), bones have been replaced with a chalky version of calcium cabonate that closely resembles the preservation style of E.? jocelynae n. sp. Because spinicaudatan carapaces are primarily chitin interlayered with limited bioapatite ( $\sim 5 \%$ phosphate compared to $\sim 40 \%$ in vertebrates), it is likely that low $\mathrm{pH}$ lake waters or early diagenetic processes, including bioerosion, could have removed the phosphate and facilitated later carbonate precipitation within voids held open by the chitin remnants. The atypical preservation exhibited by E.? jocelynae n. sp., therefore, may have been facilitated by specific geochemical or microbial conditions within the depositional environment. Additional analyses on preservation of the spinicaudatan and associated fauna of the Beaverhead Basin are in progress to investigate the relationship between preservation and geochemistry in more detail.

\section{Evolutionary and environmental significance}

Clam shrimp are common in lacustrine deposits of late Paleozoic and Mesozoic age, but rarely have been reported from Cenozoic strata (see Zhang et al., 1976; Chen and Shen, 1981; Shen et al., 2006; Gallego and Mesquita, 2010). The only previously described Cenozoic clam shrimp from North American are two species from the Eocene Green River Formation (Shen et al., 2006). These species, Cyclesteriodes wyomingensis and Prolynceus laneynsis, are members of the orders Cyclestheriida and Laevicaudata, respectively. Thus, Estherites? jocelynae n. sp. is the first spinicaudatan "conchostracan" described from the Cenozoic of North America. Estherites? jocelynae n. sp. is also the second youngest clam shrimp to have been described globally-only Paraleptestheria menglaensis (Gallego and Mesquita, 2010) from the late Oligocene of Brazil is younger.

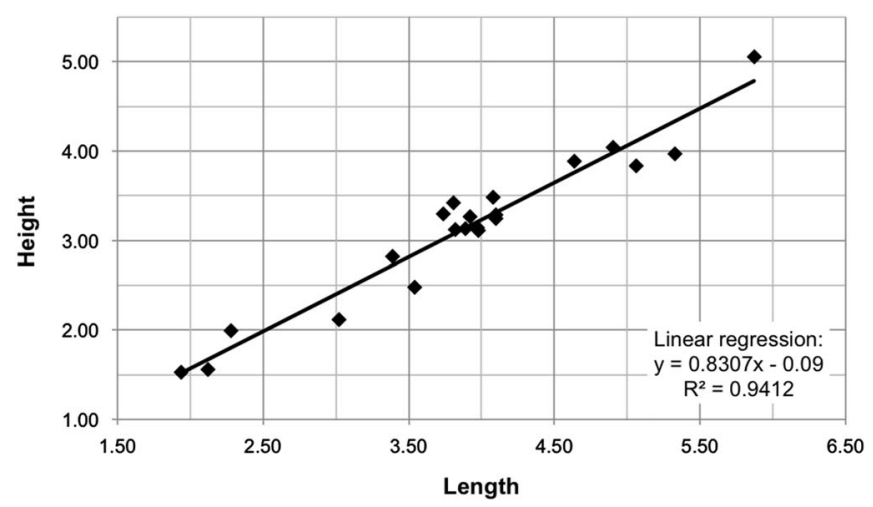

Figure 6. Growth plot of E.? jocelynae n. sp. specimens showing isometric growth; Height and Length in $\mathrm{mm}$.

All other species of Estherites are known from older deposits of northeast Asia, thus the presence of E.? jocelynae $\mathrm{n}$. sp. in the Oligocene deposits of the Beaverhead basin suggests that the ancestors of this species dispersed to North America from Asia. Lielke et al. (2012) documented an increase in the number of plant species of East Asian affinity within the Medicine Lodge Formation, and the spinicaudatans may have utilized the same dispersal pathway. Estherites? jocelynae n. sp. is also the youngest species of this genus and demonstrates the persistence of this clade beyond the Cretaceous-Paleogene extinction.

Spinicaudatans are explicit environmental indicators because they are restricted to freshwater habitats that exhibit seasonal fluctuations in water availability (Thiéry, 1996; Vannier et al., 2003). As part of their reproductive pathway, many spinicaudatans species produce cysts that must undergo drying before hatching can occur (Thiéry, 1996; Vannier et al., 2003). Thus the basic life-history attributes of spinicaudatans match the highly seasonal, summer dry climate with a mean summer temperate of $30.5^{\circ} \mathrm{C}$ reconstructed by Lielke et al. (2012) for the Beaverhead Basin quite well.

Additional fauna from the spinicaudatan-bearing locality provides further insight to the depositional environment. The presence of fish remains, ostracodes (Fig. 5.5, 5.9), insectsincluding caddisfly cases (Fig. 5.9), bivalves, and freshwater gastropods (Fig. 5.8) indicates that portions of the lake retained water year-round, although water levels likely fluctuated, allowing marginal regions to dry enough for spinicaudatan cyst development. The presence of a limited number of Planolites burrows (Fig. 5.7, 5.11) indicates that deposit feeders were present, but uncommon on the lake bottom. A fairly limited infaunal population would have facilitated the preservation of the relatively delicate spinicaudatan carapaces.

\section{Conclusions}

With the exception of Paraleptestheria menglaensis (Gallego and Mesquita, 2010) from the late Oligocene of Brazil, Estherites? jocelynae is the youngest clam shrimp described globally. This report is also the first occurrence of a spinicaudatan from the Cenozoic of North America. The description of E.? jocelynae $\mathrm{n}$. sp. extends the range of the superfamily 
Estheriteoidea into the Paleogene. The range extension, coupled with the unusual preservation style of E.? jocelynae n. sp. carapaces, suggests that the weak Cenozoic record of Spinicaudata may be related to preservation bias or perhaps changes in the distribution of lake environments, and thus the geochemistry of lakes, from the Mesozoic to Cenozoic. The presence of E.? jocelynae n. sp. in the Medicine Lodge Formation supports the interpretation that Beaverhead Basin experienced strongly seasonal climate, as inferred from paleobotanical proxies.

\section{Acknowledgments}

Useful feedback on an earlier version of this manuscript was provided by C. Haug and T. Hegna. We thank J. Hartman, D. Hembree, and S. Wing for assistance with identifications. J. Utrup and S. Butts at YPM provided access to their collections and assistance with specimen curation. F. Farelas provided ESEM access at the Ohio University Institute for Corrosion and Multiphase Technology.

\section{Accessibility of supplemental data}

Data available from the Dryad Digital Repository : http://dx.doi. org/10.5061/dryad.8217f

\section{References}

Astrop, T.I., and Hegna, T.A., 2015, Phylogenetic relationships between living and fossil spinicaudatan taxa (Branchiopoda Spinicaudata): reconsidering the evidence: Journal of Crustacean Biology, v. 35, p. 339-354.

Astrop, T.I., Sahni, V., Blackledge, T.A., and Stark, A.Y., 2015, Mechanical properties of the chitin-calcium-phosphate "clam shrimp" carapace (Branchiopoda: Spinicaudata): implications for taphonomy and fossilization: Journal of Crustacean Biology, v. 35, p. 123-131.

Becker, H.F., 1969, Fossil plants of the Tertiary Beaverhead Basins in Southwestern Montana: Palaeontographica, Abteilung B, v. 127, p. 1-142.

Berner, R.A., 1968, Calcium carbonate concretions formed by the decomposition of organic matter: Science, v. 158, p. 195-197.

Boukhalfa, K., Li, G., Ben Ali, W., and Soussi, M., 2015, Early Cretaceous spinicaudatans ("conchostracans") from lacustrine strata of the Sidi Aïch Formation in the northern Chotts range, southern Tunisia: taxonomy, biostratigraphy and stratigraphic implication: Cretaceous Research, v. 56, p. 482-490.

Cavender, T.M., 1977, A new Tertiary fish fauna from southwestern Montana: Geological Society of America Abstracts with Programs, v. 9, p. 715.

Chen, P.-J., and Shen, Y.-B., 1981, Paleogene conchostracan faunas of China: Geological Society of America Special Papers, v. 187, p. 193-202.

Chen, P.-J., and Shen, Y.-B., 1985, An Introduction to Fossil Conchostraca: Beijing, Science Press, 241 p.

DeVore, M.L., and Pigg, K.B., 2010, Floristic composition and comparison of middle Eocene to late Eocene and Oligocene floras in North America: Bulletin of Geosciences, v. 85, p. 111-134.

Fernández-Jalvo, Y., Pesquero, M. D., and Tormo, L., 2016, Now a bone, then calcite: Palaeogeography, Palaeoclimatology, Palaeoecology, v. 444, p. $60-70$.

Gallego, O.F., and Mesquita, M.V., 2010, First record of Oligocene conchostracans (Tremembé Formation, Taubaté Basin) from São Paulo, Brazil: Journal of South American Earth Sciences, v. 13, p. 685-692.

Gallego, O.F., Cabaleri, N.G., Armella, C., Volkheimer, W., Ballent, S.C., Martínez, S., Monferran, M.D., Silva Nieto, D.G., and Páez, M.A., 2011, Paleontology, sedimentology and paleoenvironment of a new fossiliferous locality of the Jurassic Cañadón Asfalto Formation, Chubut Province, Argentina: Journal of South American Earth Sciences, v. 31, p. 54-68.

Gerstaecker, A., 1866, Crustacea (Erste Hälfe), in Bronn, H.G., ed., Die Klassen und Ordnungen der Thier-Reichs, Volume 5 (Part 1: Arthropoda): Leipzig, C.F. Winter, $1320 \mathrm{p}$.

Gierlowski-Kordesch, E.H., and Kelts, K.R., 2000, Lake Basins through Space and Time, in Huntley, N.F., ed., AAPG Studies in Geology, Volume 46: Tulsa, OK, American Association of Petroleum Geologists, p. 648.
Graham, A., 1999, Late Cretaceous and Cenozoic History of North American Vegetation North of Mexico: New York, Oxford University Press, $350 \mathrm{p}$.

Hethke, M., Fürsich, F.T., Jiang, B., and Pan, Y., 2013, Seasonal to sub-seasonal palaeoenvironmental changes in Lake Sihetun (Lower Cretaceous Yixian Formation, NE China): International Journal of Earth Sciences, v. 102, p. 351-378.

Janecke, S., Mcintosh, W., and Good, S., 1999, Testing models of rift basins: structure and stratigraphy of an Eocene-Oligocene supradetachment basin, Muddy Creek half graben, south-west Montana: Basin Research, v. 11, p. 143-165.

Keenan, S.W., Engel, A.S., Roy, A., and Bovenkamp-Langlois, G.L., 2015, Evaluating the consequences of diagenesis and fossilization on bioapatite lattice structure and composition: Chemical Geology, v. 413, p. 18-27.

Kobayashi, T., and Huzita, A., 1942, Estheriae in the Cretaceous Sungari Series in Manchoukuo: Journal of the Faculty of Science, Imperial University of Tokyo, Section 2, v. 6, p. 107-128.

Kobayashi, T., and Huzita, A., 1943, On Estherites, new genus: Journal of the Geological Society of Japan, v. 50, p. 196-202.

Kozur, H.W., and Weems, R.E., 2010, The biostratigraphic importance of conchostracans in the continental Triassic of the Northern Hemisphere, in Lucas, S.G., ed., The Triassic Timescale: Geological Society, London, Special Publications: London, Geological Society of London, p. 315-417.

Latreille, P.A., 1817, Le Regne Animal. Tome III, Contenant les Crustacés, les Arachnides et les Insectes: Paris, A. Bedin, 653 p.

Lewis, S.E., 1972, Fossil caddisfly (Trichoptera) cases from the Ruby River Basin (Oligocene) of Southwestern Montana: Annals of the Entomological Society of America, v. 65, p. 518-519.

Li, G., and Batten, D.J., 2005, Revision of the conchostracan genus Estherites from the Upper Cretaceous Nenjiang Formation of the Songliao Basin and its biogeographic significance in China: Cretaceous Research, v. 26, p. 920-929.

Lielke, K., Manchester, S., and Meyer, H., 2012, Reconstructing the environment of the Northern Rockies during the Eocene/Oligocene Transition: constraints from the paleobotany and geology of Southwestern Montana, USA: Acta Palaeobotanica, v. 52, p. 317-358.

Linder, F., 1945, Affinities within the Branchiopoda with notes on some dubious fossils: Arkiv för Zoology, v. 37A, p. 1-28.

Lucas, S.G., and Milner, A.R.C., 2006, Conchostraca from the Lower Jurassic Whitmore Point Member of the Moenave Formation, Johnson Farm, Southwestern Utah, in Harris, J.D., Lucas, S.G., Spielmann, J.A., Lockley, M.G., Milner, A.R.C., and Kirkland, J.I., eds., The Triassic-Jurassic Terrestrial Transition: New Mexico Museum of Natural History and Science, Albuquerque: Bulletin, v. 37, p. 421-423.

M'Gonigle, J.W., and Dalrymple, G.B., $1993,{ }^{40} \mathrm{Ar} /{ }^{39} \mathrm{Ar}$ ages of Challis Volcanic rocks and the initiation of Tertiary sedimentary basins in Southwestern Montana: The Mountain Geologist, v. 30, p. 112-118.

M'Gonigle, J.W., and Dalrymple, G.B., $1996,{ }^{40} \mathrm{Ar} /{ }^{39} \mathrm{Ar}$ ages of some Challis Volcanic Group rocks and the initiation of Tertiary sedimentary basins in Southwestern Montana: U.S. Geological Survey Bulletin, v. 2132, p. 1-17.

Martin, J.W., and Davis, G.E., 2001, An updated classification of the Recent Crustacea: Natural History Museum of Los Angeles County, Science Series, v. 39, p. $1-124$.

Martínez-Delclòs, X., Briggs, D.E.G., and Peñalver, E., 2004, Taphonomy of insects in carbonates and amber: Palaeogeography, Palaeoclimatology, Palaeoecology, v. 203, p. 19-64.

McCobb, L.M.E., Duncan, I.J., Jarzembowski, E.A., Stankiewicz, B.A., Wills, M.A., and Briggs, D.E.G., 1998, Taphonomy of the insects from the Insect Bed (Bembridge Marls), late Eocene, Isle of Wight, England: Geological Magazine, v. 135, p. 553-563.

Monferran, M. D., Gallego, O. F., Astrop, T. I., and Cabaleri, N., 2013, Autecology of Wolfestheria smekali (Spinicaudata) from the Upper Jurassic (Cañadón Asfalto Formation), Patagonia, Argentina: Palaeogeography, Palaeoclimatology, Palaeoecology, v. 392, p. 52-61.

Olempska, E., 2004, Late Triassic spinicaudatan crustaceans from southwestern Poland: Acta Palaeontologica Polonica, v. 49, p. 429-442.

Olesen, J., 2000, An updated phylogeny of the Conchostraca-Cladocera clade (Branchiopoda, Diplostraca): Crustaceana, v. 73, p. 869-886.

Olesen, J., 2009, Phylogeny of Branchiopoda (Crustacea)-character evolution and contribution of uniquely preserved fossils: Athropod Systematics and Phylogeny, v. 67, p. 3-39.

Orr, P.J., and Briggs, D.E.G., 1999, Exceptionally preserved conchostracans and other crustaceans from the Upper Carboniferous of Ireland: Special Papers in Palaeontology, v. 62, p. 1-68.

Orr, P.J., Briggs, D.E.G., and Kearns, S.L., 2008, Taphonomy of exceptionally preserved crustaceans from the Upper Carboniferous of southeastern Ireland: Palaios, v. 23, p. 298-312.

Park, L.E., and Downing, K.F., 2001, Paleoecology of an exceptionally preserved arthropod fauna from lake deposits of the Barstow Formation, Southern California, USA: Palaios, v. 16, p. 175-184.

Park, L.E., and Gierlowski-Kordesch, E.H., 2007, Paleozoic lake faunas: establishing aquatic life on land: Palaeogeography, Palaeoclimatology, Palaeoecology, v. 249, p. 160-179. 
Richter, S., Olesen, J., and Wheeler, W.C., 2007, Phylogeny of Branchiopoda (Crustacea) based on a combined analysis of morphological data and six molecular loci: Cladistics, v. 23, p. 301-336.

Sagemann, J., Bale, S.J., Briggs, D.E.G., and Parkes, R.J., 1999, Controls on the formation of authigenic minerals in association with decaying organic matter; an experimental approach: Geochimica et Cosmochimica Acta, v. 63, p. 1083-1095.

Scholten, R., Keenmon, K.A., and Kupsch, W.O., 1955, Geology of the Lima region, southwestern Montana and adjacent Idaho: Geological Society of America Bulletin, v. 66, p. 345-404.

Scholze, F., and Schneider, J.W., 2015, Improved methodology of 'conchostracan' (Crustacea: Branchiopoda) classification for biostratigraphy: Newsletters on Stratigraphy, v. 48, p. 287-298.

Schwentner, M., Timms, B.V., Bastrop, R., and Richter, S., 2009, Phylogeny of Spinicaudata (Branchiopoda, Crustacea) based on three molecular markers - an Australian origin for Limnadopsis: Molecular Phylogenetics and Evolution, v. 53, p. 716-725.

Shen, Y.-B., Gallego, O.F., and Martínez, S., 2004, The conchostracan subgenus Orthestheria (Migransia) from the Tacuarembó Formation (Late Jurassic-? Early Cretaceous, Uruguay) with notes on its geological age: Journal of South American Earth Sciences, v. 16, p. 615-622.

Shen, Y.-B., Gallego, O.F., Buchheim, H.P., and Biaggi, R.E., 2006, Eocene conchostracans from the Laney Member of the Green River Formation, Wyoming, USA: Journal of Paleontology, v. 80, p. 447-454.

Siebold, C.T. von, 1848, Lehrbuch der vergleichenden Anatomie der Wirbel-losen Thiere. Erster Theil, in von Siebold, C.T., and Stannius, H., eds., Lehrbuch der vergleichenden Anatomie: Berlin, Verlag von Veit \& Comp., 679 p.

Stenderup, J.T., Olesen, J., and Glenner, H., 2006, Molecular phylogeny of the Branchiopoda (Crustacea)-Multiple approaches suggest a 'diplostracan' ancestry of the Notostraca: Molecular Phylogenetics and Evolution, v. 41, p. 182-194.

Stigall, A.L., and Hartman, J.H., 2008, A new spinicaudatan genus (Crustacea: 'Conchostraca') from the Late Cretaceous of Madagascar: Palaeontology, v. 51 , p. $1053-1067$.

Stigall, A.L., Babcock, L.E., Briggs, D.E.G., and Leslie, S.A., 2008, Taphonomy of lacustrine interbeds in the Kirkpatrick Basalt (Jurassic), Antarctica: Palaios, v. 23, p. 344-355.
Stigall, A.L., Hembree, D.I., Gierlowski-Kordesch, E.H., and Weismiller, H.C., 2014, Evidence for a dioecious mating system in Early Jurassic Hardapestheria maxwelli gen. et sp. nov. (Crustacea, Branchiopoda, Spinicaudata) from the Kalkrand Formation of Namibia: Palaeontology, v. 57, p. 127-140.

Tasch, P., 1987, Conchostraca of the Southern Hemisphere and continental drift: paleontology, biostratigraphy, and dispersal: Geological Society of America Memoir, v. 165, p. 1-290.

Thiéry, A., 1996, Branchiopodes. I. Ordres des anostracés, notostracés, Spinicaudata et Laevicaudata (Anostraca Sars, 1867-Notostraca Sars, 1867-Spinicaudata Linder-1945, Laevicaudata Linder-1945), in Forest, J., ed., Traité de Zoologie, Anatomie, Systématique, Biologie, Tome VII, Crustacés, Fascicule 2, Généralités (suite) et Systématique: Paris, Masson, p. 285-351.

Vannier, J., Thiéry, A., and Racheboeuf, P.R., 2003, Spinicaudatans and ostracods (Crustacea) from the Montceau Lagerstatte (Late Carboniferous, France): morphology and palaeoenvironmental significance: Palaeontology, v. 46 , p. $999-1030$.

Walossek, D., 1999, On the Cambrian diversity of Crustacea, in Schram, F.R., and von Vaupel Klein J.C., eds., Crustaceans and the Biodiversity Crisis, Proceedings of the Fourth International Crustacean Congress, Amsterdam, The Netherlands, July 20-24, 1998: Leiden, Brill Academic Publishers, v. 1 , p. $3-27$

Wing, S.L., 1987, Eocene and Oligocene floras and vegetation of the Rocky Mountains: Annals of the Missouri Botanical Garden, v. 74, p. 748-784.

Zhang, W.-T., Chen, P.-J., and Shen, Y.-B., 1976, Fossil Conchostraca of China: Beijing, Science Press, 325 p. (in Chinese).

Accepted 24 February 2017

\section{Appendix}

Appendix 1. Morphological characteristics of specimens examined. (Data available from the Dryad Digital Repository : http://dx.doi.org/10.5061/dryad.8217f.) 